\title{
Corolla of Roselle (Hibiscus sabdariffa L.) as acid-base indicator
}

\author{
Siti Nuryanti a, Sabirin Matsjeh b, Chairil Anwar b, Tri Joko Raharjo b and Baharuddin Hamzah a,* \\ a Department of Chemistry, Faculty of Teacher Training and Education, Tadulako University, Palu, 94118, Indonesia \\ b Department of Chemistry, Faculty of Mathematics and Natural Sciences, Gadjah Mada University, Yogyakarta, 55185, Indonesia \\ *Corresponding author at: Department of Chemistry, Faculty of Teacher Training and Education, Tadulako University, Palu, 94118, Indonesia. \\ Tel.: +62.451.481356; fax: +62.451.429743. E-mail address: hamzahhb@yahoo.com (B. Hamzah).
}

\section{ARTICLE INFORMATION}

Received: 22 April 2012

Received in revised form: 15 August 2012

Accepted: 15 August 2012

Online: 31 March 2013

\section{KEYWORDS}

Indicator

Methyl orange

Phenolphthalein

Corolla of Roselle

Acid-base titration

Hibiscus sabdariffa L.

\begin{abstract}
Acid-base titration requires indicators to show color change at each pH interval. Synthetic indicators applied recently have some negatives, such as chemical pollution, availability and expensive production cost. Effort to obtain natural product-based-indicator from corolla of Roselle (Hibiscus sabdariffa L.) has been conducted. Firstly, anthocyanin contained in the Roselle's corolla was identified. Then, the indicator was obtained by extracting the corolla consecutively with $\mathrm{n}$-hexane, ethyl acetate and methanol- $\mathrm{HCl} 0.5 \%$. Then the filtrate was evaporated at $65{ }^{\circ} \mathrm{C}$. The obtained indicator was applied in weak base-strong acid and weak acid-strong base titrations. The comparison indicators used in this research were methyl orange and phenolphthalein. The results showed that the Roselle's corolla indicator gave red color in acidic solution, while green in basic solution. Additionally, its performance is similar to that of methyl orange.
\end{abstract}

\section{Introduction}

Roselle (Hibiscus sabdariffa $\mathrm{L}$ ) is easily cultivated either in tropical or subtropical area and start flowering at the age of 3-4 months. This plant has different names in several countries, such as rozelle, sorell, red sorell (England), oiselle de guince (France), rose de Jamaica (Spain), karkade (South Africa), karkade (Arab) and krachiap daeng or wolof (Thailand). Roselle (Figure 1) biologically can be classified as follows: Kingdom: Plantae, Subkingdom: Tracheobionta Divisi: Magnoliophyta, Ordo: Malvales, Famili: Malvaceae, Genus: Hibiscus, Spesies: Hibiscus sabdariffa L.

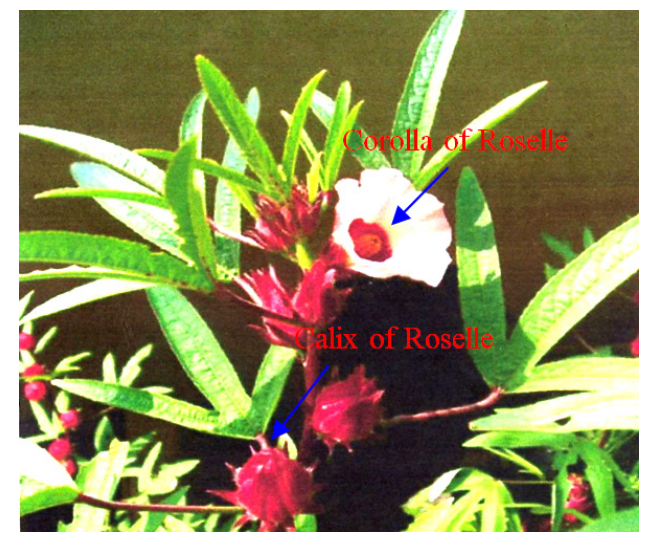

Figure 1. Roselle (Hibiscus sabdariffa L.)

Dried petal of Roselle is mainly used for food, beverages (tea) as well as food coloring agent, as it has been known that it contains anthocyanins, delvinidin-3-monoglucosyde and cyanidin-3-monoglucoside [1,2]. Anthocyanins are generally found in red, purple and blue flowers. Anthocyanins tends to have no color in solution with neutral $\mathrm{pH}$ value, intense red in very acidic solution (when $\mathrm{pH}$ is increased to neutral $\mathrm{pH}$, the color will begin to fade even be colorless) and blue in basic solution [3,4]. The application of red anthocyanin-containedflower, likes Roselle, has not been optimal yet. Corolla of Roselle, as an example, usually thrown away as waste. Therefore a research to proving that corolla of Roselle has anthocyanins and these natural indicators are needed. This mainly due to the synthetic acid-base indicators like methyl orange and phenolphthalein have some negatives such as availability and expensive production cost [5]. Those facts lead to the laboratory works (especially in the topic of acid-base) at high school in rural areas. The problem can be overcome if Roselle can be used as indicator to replace methyl orange and phenolphthalein.

This research was aimed to identify the anthocyanins in the corolla of Roselle, make acid-base indicator from the corolla as well as to apply the obtained indicator in acid-base titration: weak acid-strong base and weak base-strong acid (with the comparison against methyl orange and phenolphthalein).

\section{Experimental}

\subsection{Materials}

The chemicals used in this study were sodium hydroxide, ammonia, acetic acid, hydrochloric acid, sodium bicarbonate, $\mathrm{Pb}$-acetate, methyl orange (mo), phenolphthalein (pp), nhexane and methanol. All chemicals were purchased from $\mathrm{E}$. Merck with high quality grade. Roselle (Hibiscus sabdariffa L.) was obtained from Trisik, Kulon Progo, Yogyakarta, Indonesia. Identification of this plant was conducted in Laboratory of Plant Taxonomy, Faculty of Biology, Gadjah Mada University, Yogyakarta, Indonesia. 


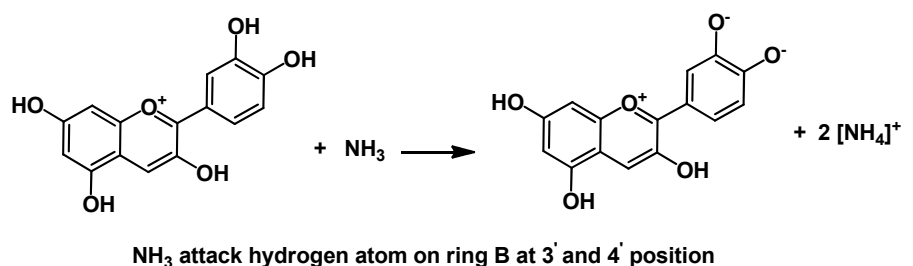

Figure 3. Reaction between anthocyanin from corolla Roselle and $\mathrm{NH}_{3}$ vapor.

\subsection{Instrumentation}

The instruments used in this study were shaker (IKA ${ }^{\circledR} \mathrm{KS}$ 130 basic), rotary evaporator (Buchii R-124), Buchner funnel, pH-meter (Hanna HI-8314), micro buret (JENCONS Scientific USA), micro pipette (SOLOREK Swiss), pipette, magnetic stirrer, analytical balance (Libror EB-330 Shimadzu) and UV-Vis spectrophotometer (Miltonroy array 3000).

\subsection{Procedures}

\subsubsection{Identification of anthocyanin in the corolla of Roselle}

As much as $5.000 \mathrm{~g}$ of Roselle corolla was extracted using $25 \mathrm{~mL}$ of methanol. The extract was then concentrated, colortested using ammonia vapor as well as solution of $\mathrm{Pb}$-acetate $1 \%$ and analyzed by means of UV-Vis spectrophotometer.

\subsubsection{Production of acid base indicator from the corolla of Roselle extract}

Corolla of Roselle (500 g) was washed with aquades, cut into small pieces and extracted with $2.5 \mathrm{~L}$ of n-hexane for 20 hrs. The extract was filtered, while the residue was re-extracted using $2.5 \mathrm{~L}$ of ethyl acetate for $20 \mathrm{hrs}$. Next, the residue was extracted with methanol-HCl $0.5 \%(2.5 \mathrm{~L})$ for $20 \mathrm{hrs}$. The extract was then filtered and the filtrate was concentrated using rotary evaporator.

\subsubsection{Corolla of Roselle extract as acid-base indicator}

\subsubsection{Weak base-strong acid titration}

In this research, titration procedures, preparation and selection of reference indicators were based on Day and Underwood [6]. Into Erlenmeyer, as much as $45 \mathrm{~mL}$ of $\mathrm{NaHCO}_{3}$ solution and 10-20 drops of indicator of Roselle's corolla were placed, where the solution turned green. The mixture was titrated with standardized $\mathrm{HCl} 0.1 \mathrm{~N}$. The titration was stopped when the color of solution mixture turned red. The same procedure was performed for the reference indicator of methyl orange instead of Roselle's corolla indicator.

\subsubsection{Weak acid-strong base titration}

Acetic acid (45 mL) and 10-20 drops of Roselle's corolla indicator were putted in erlenmeyer and the color of solution would turn pink. The solution was titrated using standardized $0.1 \mathrm{~N} \mathrm{NaOH}$. Titration was stopped when the color of solution turned green. For comparison, the same titration procedure was also conducted using the indicator of phenolphthalein.

\section{Results and discussion}

\subsection{Identification of anthocyanin in the corolla of Roselle}

The color of extract of Roselle's corolla was red. UV-Vis analysis (Figure 2) gave absorption at the maximum wavelength $\left(\lambda_{\max }\right)$ of $536 \mathrm{~nm}$ (Band I) and $281 \mathrm{~nm}$ (Band II). This characteristic of absorption indicated that the extract of Roselle corolla contained anthocyanin of cyanidin $[3,7,8,9]$. Anthocyanin can be readily distinguished from other flavonoid classes by performing color test and UV-Vis analysis ( $\left.\lambda_{\text {maks }}\right)$. Anthocyanin in methanol- $\mathrm{HCl} 0.01 \%$ produces characteristic spectrum with two absorptions at both $270-280 \mathrm{~nm}$ (Band II) and 465-560 nm (Band I). Almost all flavonoid classes give the same absorption at the region of band II, thus, anthocyanin can be distinguished with the other classes by observing the absorption region wavelength of band I [9].

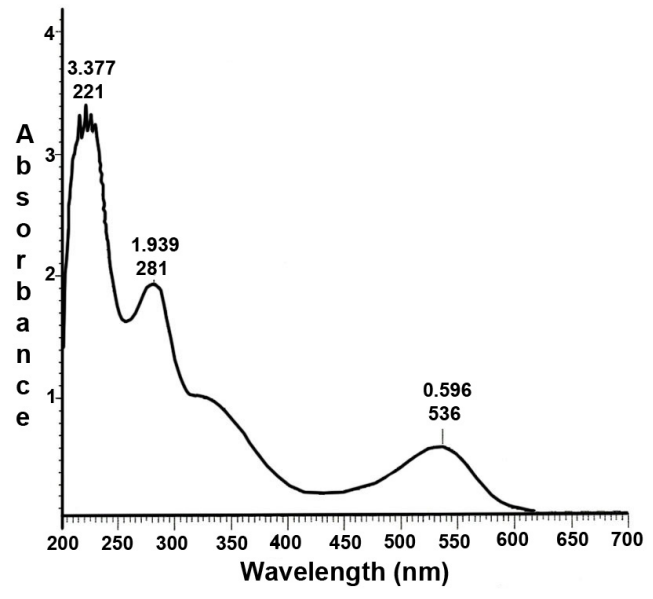

Figure 2. UV-Vis spectrum of Roselle's corolla extract.

Color test using $\mathrm{NH}_{3}$ vapor showed that before exposure, the extract gave red color, while after exposure, it was blue. This phenomenon was due to the reaction between the anthocyanin and $\mathrm{NH}_{3}$ vapor to give quinoid base as presented in Figure 3.

The same color change also occurred when the extract was reacted with the solution of $\mathrm{Pb}$-acetate. This change could be explained by the blue complex formation between anthocyanin from corolla Roselle and $\mathrm{Pb}$ metal as displayed in Figure 4.

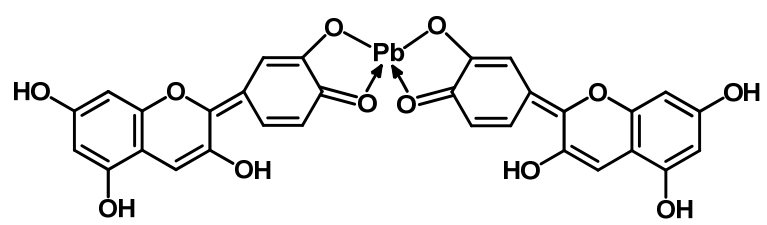

Figure 4. Blue complex of Pb-anthocyanin.

Complex formation occurred as the anthocyanin contained flavilium ion with hydroxyls group at the position of 3,5,7,3' and 4' [10]. According to UV-Vis and color analyses, it could be stated that the extract of Roselle's corolla had the anthocyanin of cyanidin. 
Table 1. Titration condition with the indicator of Roselle's corolla extract and the reference indicator of mo and pp.

\begin{tabular}{|c|c|c|c|c|}
\hline \multirow[t]{3}{*}{ Indicator } & \multicolumn{4}{|c|}{ Titration condition } \\
\hline & \multicolumn{2}{|c|}{ Weak acid-strong base } & \multicolumn{2}{|c|}{ Weak base-strong acid } \\
\hline & Volume (0.1 N NaOH, mL) & Color change & Volume (0.1 N HCl, mL) & Color change \\
\hline Roselle's corolla e & $45.30 \pm 0.350$ & Red-green, $\mathrm{pH}:$ 5.85-9.55 & $45.38 \pm 0.35$ & Green-red, pH: 4.19-3.09 \\
\hline Phenolphthalein & $45.23 \pm 0.342$ & Colorless-red, $\mathrm{pH}: 5.70-9.10$ & - & - \\
\hline Methyl orange & - & - & $45.23 \pm 0.30$ & Yellow-red, pH: 4.55- 3.00 \\
\hline
\end{tabular}<smiles>COC1=Cc2c(O)cc(O)cc2O[C@H]1c1ccc(O)c(O)c1</smiles><smiles>C1C[As][13CH]1</smiles><smiles>[Y19][C]1C=C1</smiles><smiles>[O-]OC1=Cc2c(O)cc(O)cc2OC1(O)c1ccc(O)c(O)c1</smiles>

(III)<smiles>C1=C[C@H]2C=C[C@H]1C2</smiles><smiles>Oc1cccc(O)c1</smiles><smiles>O=C(/C=C(\O)c1c(O)cc(O)cc1O)c1ccc(O)c(O)c1</smiles>

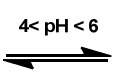<smiles>COc1cc2c(O)cc(=O)cc-2oc1-c1ccc(O)c(O)c1</smiles>

Green<smiles>C[C@@H]1CC[C@@H]1[18OH]</smiles><smiles>COc1cc2c(O)cc(=O)cc-2oc1-c1ccc(O)c(O)c1</smiles>

Figure 5. Equilibrium of flavilium cation of anthocyanin in various $\mathrm{pH}$ [11].

\subsection{Corolla of Roselle extract as acid-base indicator}

Results of application of Roselle's corolla extract as indicator in weak base-strong acid and weak acid-strong base titrations were tabulated in Table 1.

Color change of indicator of Roselle's corolla extract in weak acid-strong base titration was red-green with the titration's end point of 7.30-9.55. On the other hand, Roselle indicator gave color change of green-red in weak base-strong acid titration with the end point of 4.19-3.09 (Table 1). The $\mathrm{pH}$ range of the reference indicator of pp and mo are 8.0-9.6 and 4.4-3.1, respectively [6]. The results showed that the $\mathrm{pH}$ range of Roselle indicator was in the range of MO, thus this natural product could be applied as indicator in weak base-strong acid titration. Anthocyanin in Roselle's corolla had flavilium cation which, was unstable in the change of $\mathrm{pH}$ solution. Change of $\mathrm{pH}$ might make the change of structure that led the color change.
Change of structure of anthocyanin in various $\mathrm{pH}$ values is shown in Figure 5.

Anthocyanin (Structure I), in acidic condition was red. When $\mathrm{pH}$ increased $(\mathrm{pH}<4)$, colorless carbinolbase (III) would be formed. Tautomer occurred to produce chalcone (IV). At $\mathrm{pH}$ $<6$ the structure changed into anhydrobase (II). Extension of conjugation in this structure gave color change to be blue with stronger intensity and maximum wavelength of $\lambda_{\max } 610 \mathrm{~nm}$ [11].

It was observed that Roselle's corolla extract was green tosca at $\mathrm{pH}$ 8. UV-Vis spectrum (Figure 6) also gave maximum wavelength at $611 \mathrm{~nm}$. These indicated that extract of Roselle's corolla contained anthocyanin and can be applied as acid-base indicator. Organic compound that can be applied as indicator in titration have characteristic in color change in various $\mathrm{pH}$ of solution. Color change might be happened through equilibrium process of molecule and ion of the indicator. 


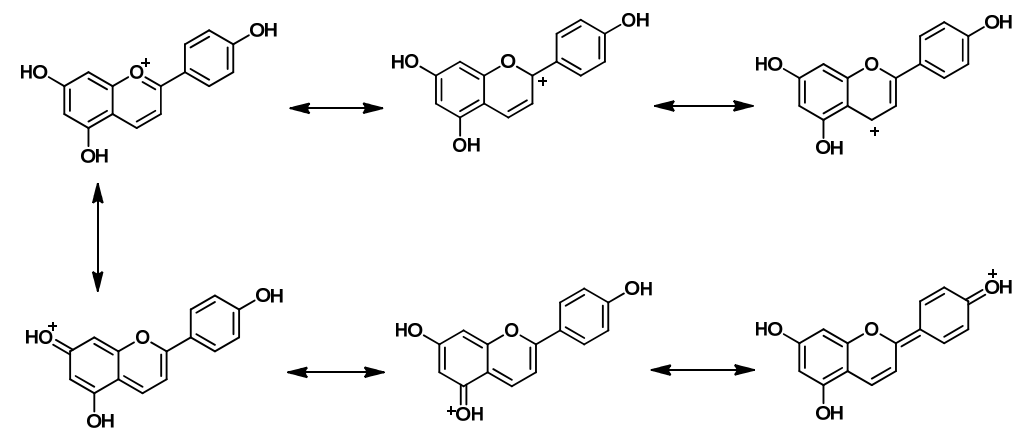

Figure 8. Delocalization charge on flavilium cation [3].
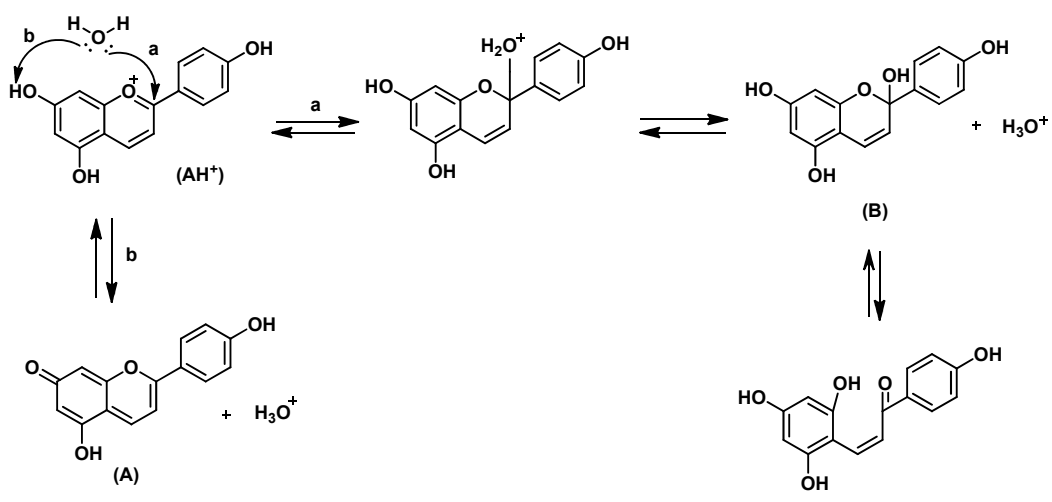

(C)

Figure 9. Reaction of flavilium cation from apigenidin into quinoid (A), pseudobase carbinol (B) and chalcone (C).

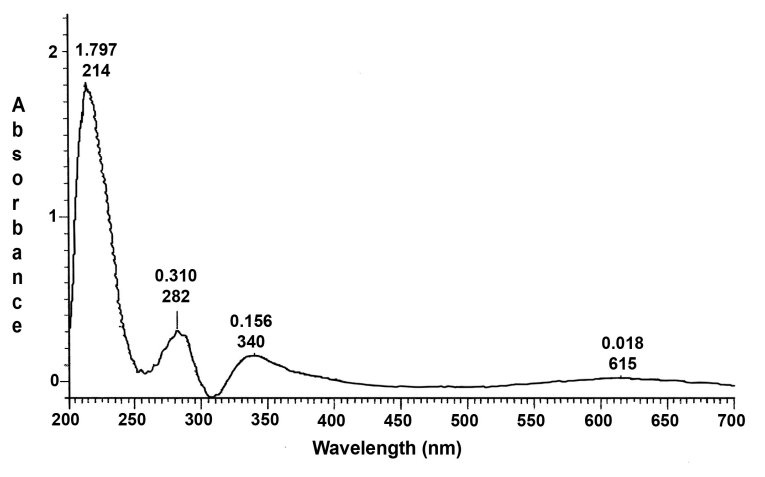

Figure 6. UV-Vis spectrum of Roselle's corolla extract in buffer solution of $\mathrm{pH}=8$.

As an example is phenolphthalein, which undergo ionic equilibrium that lead color change from colorless in acidic condition to red in basic condition. The color change occurs due to the delocalization of phenolic ion to give quinoid as presented in Figure 7 [12].

Structurally, anthocyanin contained flavilium cation which, had conjugated double bond, thus led delocalization of positive charge to the whole molecule and gave some resonance structure (Figure 8).

Effect of resonance caused the pigment structure be more stable as flavilium cation [7]. If nucleophile attacks carbon atom 2 (Step a), pseudobase carbinol (B) will be formed. This species would undergo isomerization into chalcone (c) via watercatalyzed-tautomerization. Then, if a base attacks hydrogen atom of hydroxyl group (Step b), quinoid will be formed (Figure
9). The formation of quinoid would extend the delocalization, thus, gave color change from red in acidic condition to green in basic condition $[13,14]$. Therefore, based on Table 1, extract of Roselle's corolla might substitute the indicator of methyl orange.

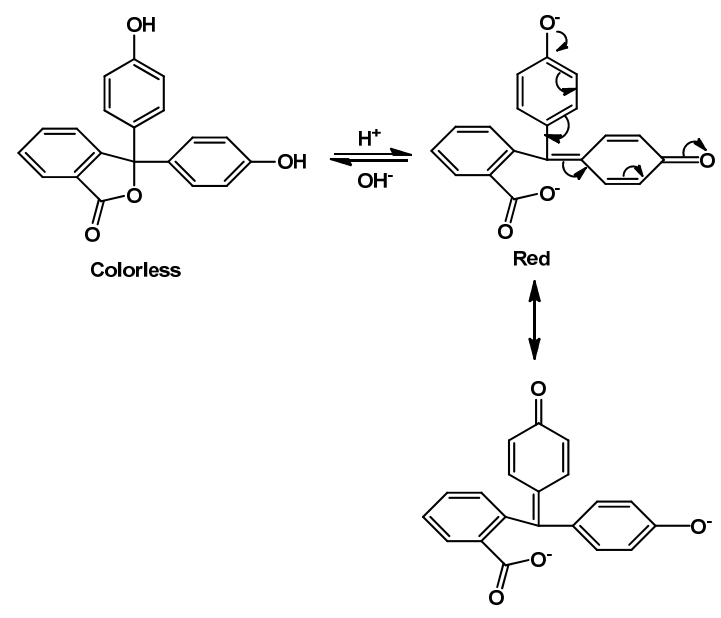

Figure 7. Equilibrium of phenolphthalein.

\section{Conclusion}

Extract of corolla of Roselle (Hibiscus sabdariffa L) could be utilized as indicator in acid-base (weak acid-strong base and weak base-strong acid) titration. The extract displayed red color in acidic solution and red in basic solution. The color 
change occurred due to anthocyanins contained on the extract, where its structure bearing flavilium cation. The Roselle indicator had $\mathrm{pH}$ range, similar to that of methyl orange, therefore, it could be applied in acid-base titrations.

\section{Acknowledgements}

The author would thank to General Directorate of Higher Education, Ministry of National Education Republic of Indonesia, which has given research fund through Gadjah Mada University Doctoral Research Grant Program, with contract number of LPPM-UGM/1215/2009 Date, May 19th 2009.

\section{References}

[1]. Amor, B.; Allaf, K. J. Food Chem. 2009, 115, 820-825.

[2]. Ologundudu, A.; Ologundudu, A. O.; Ololade, I. A.; Obi, F. O. Afr. J. Biochem. Res. 2009, 3(4), 140-144.

[3]. Harborne, J. B. Phytochemical Methods. A Guide to Modern Techniques of Plant Analysis, 2nd edition, Chapman \& Hall, 1984.

[4]. Torskangerpoll; Andersen, Q. M. J. Food Chem. 2004, 89, 427-444.

[5]. Bhagat, V. C.; Radheshyam, D. P.; Channerker, R. P.; Shetty, S. C.; Atul, A. S. J. Green Pharm. 2008, 2(3), 162-163.

[6]. Day, R. A.; Underwood, A. L. Quantitative Analysis, 6 $6^{\text {th }}$ edition, Prentice-Hall, 1998.

[7]. Harbone, J. B. J. Biochem. 1958, 70, 22-28.

[8]. Jackman, R. L.; Yada, R. Y.; Tung, M. A.; Speers, R. A. J. Food Biochem. 1987, 11, 179-208.

[9]. Andersen, Q. M.; Markham, K. R. Flavanoids: Chemistry, Biochemistry and Applications, Tailor \& Francis, 2006.

[10]. Ukwueze, N. N.; Nwadinigwe, C. A.; Okoye, C. O. B.; Okoye, F. B. C. J. Phys. Sci. 2009, 4(2), 058-062.

[11]. Mabry, T. J.; Markham, K. R.; Thomas, M. B. The Systematic Identification of Flavonoids, Springer Verlag, 1970.

[12]. Purwono, B.; Mahardani, C. Indo. J. Chem. 2009, 9(1), 95-98.

[13]. Brouillard, R.; Delaporte, J. Am. Chem. Soc. 1977, 99, 8461-8468.

[14]. Brouillard, R.; Iacobucci, G. A.; Sweeny, J. G. J. Am. Chem. Soc. 1982, 104, 7585-7590. 